\title{
Investigation of Portable Groundwater Quality and Health Risk Assessment of Selected Trace Metals in Flood Affected Areas of District Rajanpur, Pakistan
}

\author{
Sarfraz $M^{1 *}$, Sultana $\mathbf{N}^{2}$, Jamil $\mathbf{M D}^{2}$ and Ashraf $\mathbf{R}^{2}$
}

${ }^{1}$ Pakistan Council of Research in Water Resources (PCRWR), MoST, Sargodha, Pakistan

${ }^{2}$ Department of Chemistry, University of Sargodha, Sargodha, Pakistan

\begin{abstract}
Groundwater contamination is an important issue due to its toxicological effects on ecosystems and impact on public health. In this view, 120 water samples collected from flood affected areas of district Rajanpur, Pakistan were assessed for physical parameters (colour, odour, $\mathrm{pH}$, turbidity and conductivity), minerals (Alkalinity, $\mathrm{Na}^{+}, \mathrm{K}^{+}, \mathrm{Ca}^{+2}$, $\mathrm{Mg}^{+2}, \mathrm{Cl}^{-}, \mathrm{SO}_{4}^{-2}$ and TDS), micronutrients $\left(\mathrm{F}^{-}, \mathrm{As}, \mathrm{Fe}, \mathrm{Mn}, \mathrm{Zn}\right.$ ) and microbiological organism (total coliform and faecal coliform) to understand its suitability for human consumption and health risk associated. Analysis data revealed that 75 and $57 \%$ water samples were contaminated with total coliform and faecal coliform bacteria respectively. Other than this, a number of water samples were having high level of minerals, micronutrients and other chemical constituents. Health risk assessment due to high concentration of $\mathrm{Fe}, \mathrm{Mn}$, As and $\mathrm{Zn}$ was carried out by calculating chronic daily intake (CDI) and health risk index (HRI) for both adults and children separately. Calculated CDIs and HRIs were found in the order of $M n>A s>Z n>F e$ and $A s>M n>Z n>F e$ respectively. Results showed that HRI $>1$ for As in 46 and $37 \%$ water samples for children and adults respectively, posing serious threats to the healthy life of the local community.
\end{abstract}

Keywords: Groundwater; Contamination; Water quality; Risk assessment; Flood; Rajanpur; Pakistan

\section{Introduction}

Quality of ground water should be the leading research area for researchers as about $70 \%$ of Pakistanis are dependent on ground water for their household uses [1]. Ground water quality depends upon various things including different types of material on seepage routes, the dissolved solids and general human activities and sewerage or disposal system. Contamination of groundwater is done by different sources like natural disasters, fertilizers, residues of pesticides and other domestic and industrial wastes having different kinds of pollutants [2]. Flood, a common natural disaster, is among the main sources of water pollution which enter different kinds of contaminants like industrial, human and animal wastes into the water body through unprotected bore holes and surface water sources.

Waterborne diseases are the major threat to the healthy lives of the people. Literature shows that waterborne disease as a result of faecal pollution of drinking water wiped out entire population of cities [3]. It is estimated that nearly $80 \%$ of total diseases like diarrhoea, dysentery, tooth decay, hepatitis and anaemia in children are due to consumption of poor quality water [4]. In Pakistan over $40 \%$ of urban deaths are linked to waterborne diseases originated due to consumption of contaminated water [5]. A study conducted in Charsadda district of Khyber Pakhtunkhwa revealed that drinking water polluted with coliform bacteria was the main reason of common waterborne diseases like diarrhoea, gastroenteritis, dysentery and viral hepatitis in the region [6]

Minerals are an essential part of drinking water but excess of these beyond certain limit create complex health problems. Excess intake of calcium is directly associated with those who are prone to hypercalcaemia and milk alkali syndrome [7]. Calcium can also interact with iron, magnesium, zinc, and phosphorus within the intestine and reduces their absorption. Higher concentrations of $\mathrm{SO}_{4}$ along with $\mathrm{Na}$ and $\mathrm{Mg}$ impair water taste and have laxative effect. Similarly, higher $\mathrm{Na}$ content aid in increasing consumer's blood pressure. It has been reported that all hand pumps and $73 \%$ well water are not portable due to excess of nitrate, magnesium and sulphate in district Bannu (KPK), Pakistan [8].
Physicochemical and microbiological investigation of drinking water quality and possible health risks assessment have been carried out through a number of other studies which revealed that most of water samples have chemical and/or microbiological contamination and are unsuitable for human consumption as found in Pakistan [9-11], Cambodia [12], Ghana [13] and Bangladesh [14]. In view of above mentioned scenario and importance of drinking water quality, present study was designed to evaluate physicochemical and microbiological status of drinking water in flood affected rural areas of district Rajanpur, Pakistan.

\section{Materials and Methods}

\section{Water sampling}

Household hand pumps in flood affected areas of district Rajanpur were targeted for investigation of water quality in rural areas of district Rajanpur. From each site, three water samples were collected in clean poly propylene bottles $(600 \mathrm{ml})$ for physic-chemical, micronutrient and aesthetic parameters evaluation. Water sample for microbiological analysis from each site was collected in sterilized bottle $(250 \mathrm{ml})$ and stored in ice box and shifted to laboratory for immediate analysis.

\section{Analytical investigation}

Aesthetic and physical parameters like colour, taste, turbidity and $\mathrm{pH}$ were recorded at the sampling site using respective field testing instruments and standard methods [15]. Chemical analysis of other parameters like calcium $\left(\mathrm{Ca}^{+2}\right)$, hardness, magnesium $\left(\mathrm{Mg}^{+2}\right)$, sulphate $\left(\mathrm{SO}_{4}^{-2}\right)$, fluoride $\left(\mathrm{F}^{-}\right)$, alkalinity, chloride $\left(\mathrm{Cl}^{-}\right)$, iron $(\mathrm{Fe})$, arsenic $(\mathrm{As})$

*Corresponding author: Muhammad Sarfraz, Pakistan Council of Research in Water Resources (PCRWR), MoST, Sargodha, Pakistan, Tel: +92483252090, E-mail: sarfrazzed@gmail.com

Received May 10, 2016; Accepted June 23, 2016; Published June 29, 2016

Citation: Sarfraz MD, Sultana N, Jamil MD, Ashraf R (2016) Investigation of Portable Groundwater Quality and Health Risk Assessment of Selected Trace Metals in Flood Affected Areas of District Rajanpur, Pakistan. J Environ Anal Chem 3: 183. doi:10.41722380-2391.1000183

Copyright: (c 2016 Sarfraz MD, et al. This is an open-access article distributed under the terms of the Creative Commons Attribution License, which permits unrestricted use, distribution, and reproduction in any medium, provided the original author and source are credited. 
and TDS was done in PCRWR water quality laboratory applying APHA standard methods after proper calibration and standardization [15], whereas metals like zinc $(\mathrm{Zn})$ and manganese $(\mathrm{Mn})$ were determined by using palintest testing kit in the field. However, $10 \%$ water samples were analysed on atomic absorption spectrophotometer (AAS) for estimation of $\mathrm{Zn}$ and $\mathrm{Mn}$ and results were compared with field testing data.

\section{Microbiological analysis}

Analysis of total coliform and faecal coliform bacteria was done by adopting membrane filtration technique [16]. Water sample $(100 \mathrm{ml})$ was filtered through sterile filter paper $(0.45 \mu)$ using filtration assembly and placed on $\mathrm{m}$-Endo and $\mathrm{m}$-FC agar plate for total coliform and faecal coliform analysis respectively. Typical coliform colonies have pink to dark red colour with metallic sheen and faecal coliform colonies have blue colour are counted after incubation of $24 \mathrm{hrs}$ at $35^{\circ} \mathrm{C}$ and $45^{\circ} \mathrm{C}$ respectively.

\section{Reagent and instrumentation}

All chemicals and calibration reagent used for the study were of analytical grade and calibration of all instruments was done prior to analysis. Instruments and methods employed for evaluation of chemical parameters includes Jenway, $350 \mathrm{pH}$ meter EU, HANNA HI 99300 Italy EC meter, Louibond $\mathrm{PC}_{\mathrm{H}} 63739$ Germany turbidity meter, $\mathrm{Ca}, \mathrm{Mg}, \mathrm{Cl}$, Alkalinity and Hardness by titration method. $\mathrm{Na}$ and $\mathrm{K}$ on Flame Photometer Italy and analysis of $\mathrm{SO}_{4}$ and $\mathrm{Fe}$ were performed on Optizen 2120 UV Plus Spectrophotometer, Mecasy Co. Ltd. Korea. Fluoride was estimated on HACH DR 2800 Colorimeter and AAS were used for analysis of As whereas $\mathrm{Zn}$ and $\mathrm{Mn}$ were analysed using Palintest field testing kit and AAS. TDS was calculated by addition of cations and anions and total coliform and faecal coliform by membrane filtration assembly.

\section{Health risk assessment}

Chronic daily intake (CDI) and health risk index (HRI) of heavy metals was calculated by using the equation given below [17];

$$
\text { Chronic Daily Intake }(\mathrm{CDI})=\frac{\mathrm{Mc} \times \mathrm{Lw}}{\mathrm{Wb}}
$$

Where, $\mathrm{Mc}(\mu \mathrm{g} / \mathrm{L})$ is the metal concentration in water while $\mathrm{Lw}(\mathrm{L} /$ day) is daily water intake that is considered as $1 \mathrm{~L}$ /day and $2 \mathrm{~L} /$ day for child and adult respectively, and $\mathrm{Wb}(\mathrm{kg})$ is body weight that is assumed as $32.7 \mathrm{~kg}$ for child and $72 \mathrm{~kg}$ for adult [18].

To address chronic health problems, the health risk index was calculated by using a modified form of equation [19].

$$
\text { Health Risk Index }(\mathrm{HRI})=\frac{\mathrm{CDI}}{\mathrm{RfD}} \times 0.001
$$

Where, CDI is chronic daily intake, RfD is the reference dose for oral toxicity which is $0.0003,0.7$ and $0.3 \mathrm{mg} \cdot \mathrm{kg}^{-1} \cdot$ day $^{-1}$ for As, Fe, $\mathrm{Zn}$ and $\mathrm{Mn}$ respectively and HRI is measured health risk index, and 0.001 is the conversion factor for downscaling the reference dose (RfD) from $\mathrm{mg}$ to $\mu \mathrm{g}$. HRI<1 will be the limit for safe mode of water consumption.

\section{Results and Discussion}

Water samples collected under present investigated were assessed for physical parameters (colour, odour, $\mathrm{pH}$, turbidity and conductivity), minerals (alkalinity, $\mathrm{Na}^{+}, \mathrm{K}^{+}, \mathrm{Ca}^{+2}, \mathrm{Mg}^{+2}, \mathrm{Cl}^{-}, \mathrm{SO}_{4}^{-2}$ and TDS), micronutrients (Fe, F- As, $\mathrm{Mn}$ and $\mathrm{Zn}$ ) and microbiological constituents (total coliform and faecal coliform) and finally analysis results were compared with guidelines values.

\section{Physical parameters}

Physical and aesthetic parameters like taste, colour and turbidity of most of the water samples analysed were not objectionable with the exception of a few having saline taste. Ideally, drinking water should be colourless, odourless and tasteless. $\mathrm{pH}$ of all water samples collected and analysed ranged from 6.9-7.6 which is in close agreement with WHO guideline values of 6.5-8.5 [20].

\section{Minerals assessment}

Although, elements like $\mathrm{Na}, \mathrm{Ca}$ and $\mathrm{Mg}$ are responsible for important physiological functions in human body but an unsuitable intake and consumption of these minerals may lead towards health implications. $\mathrm{Ca}$ is considered to be an important component of basic structure of bone, soft tissues and teeth. Literature showed that short term exposure to high concentration of Ca does not create any health implications, but long time intake may lead towards hypercalcemia, urinary tract calculi and calcification in kidneys and in arterial walls besides suppression of bone remodelling [21]. Present study showed that calcium ranged from $40-460 \mathrm{mg} / \mathrm{L}$ and overall $75 \%$ water samples were having high level of calcium than guideline limits as shown in Figure 1.

Total hardness is combination of $\mathrm{Ca}, \mathrm{Mg}, \mathrm{Fe}, \mathrm{Cl}$ and $\mathrm{SO}_{4}$ ions concentrations and its high level may instigate heart diseases in residents [22]. Similarly, higher contents of $\mathrm{Cl}$ in drinking water may create problems in throat and digestive system along with imparting saline taste and corrosion [23]. Alkalinity is also an important parameter of water quality but its concentration beyond certain limit causes many problems like hardness, kidney stone, gas trouble, damage of metallic pipes and severe irritation of skin, eyes and mucous membrane [24]. High level of $\mathrm{Na}$ is associated with an increase in blood pressure in children, male and female of all ages [25]. Present study revealed that overall 19, 7.5, 27, 24, 20 and 31.5\% water samples have higher ionic concentration of $\mathrm{Cl}, \mathrm{Mg}$, hardness, $\mathrm{Na}, \mathrm{K}$ and $\mathrm{SO}_{4}$ respectively and rest of all water samples are in good agreement with WHO guidelines as shown in Figure 1.

High TDS is associated with taste, hardness, corrosion properties and tendency to incrustation. Presence of high concentration of $\mathrm{Na}, \mathrm{K}, \mathrm{Ca}, \mathrm{Cl}$, $\mathrm{SO}_{4}$ and many more minerals contribute towards high level of TDS that may cause gastrointestinal exasperation [26]. In the presented study, TDS varied from 293 to $3633 \mathrm{mg} / \mathrm{L}$ and total of 29 water samples have TDS valued higher than WHO permissible limit as shown in Figure 2.

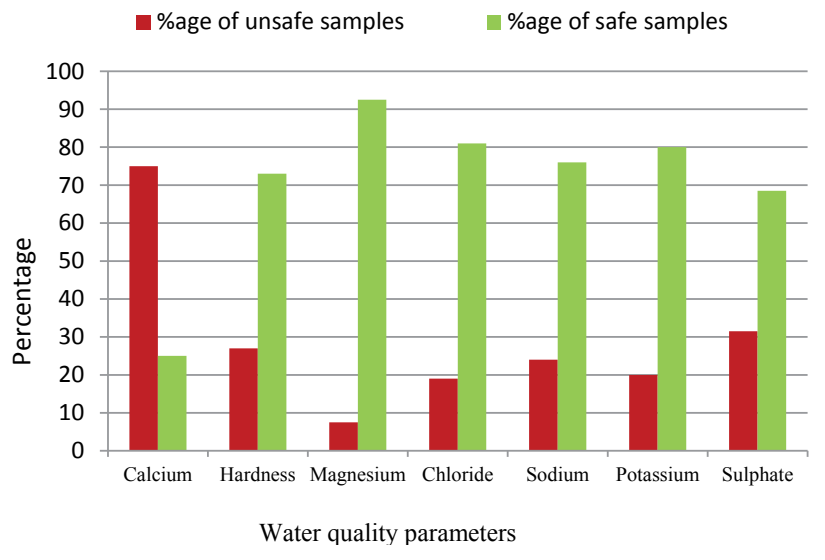

Figure 1: Water samples (\%age) safe and unsafe as compared to GVs. 


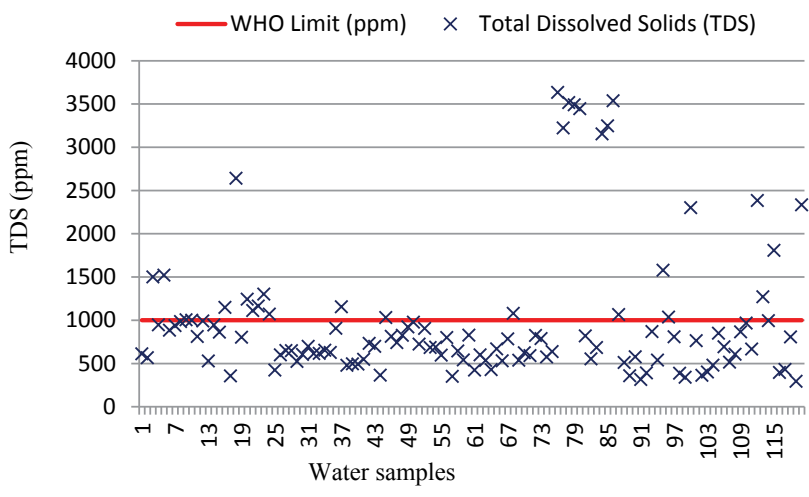

Figure 2: Comparison of measured TDS with WHO guideline value.

\section{Micronutrients}

Trace metal are associated with serious health implications depending upon the nature and quantity of the metal consumed, overall all of these metals in excess concentration are toxic [27]. Fluoride estimation in drinking water is important due to adverse health effects of its higher concentration like tooth decay and skeletal and nonskeletal fluorosis etc. among the natives [28]. Present study indicated that $\mathrm{Mn}$ and $\mathrm{Zn}$ values of all water samples analysed were within the permissible limits of WHO with the exception of 06 water samples having high concentration of zinc. On the other hand about 08,42 and $60 \%$ water samples have higher content of $\mathrm{F}^{-}$, As and Fe respectively as shown in Figure 3. It is believed that due to the interactions between the hydrological cycle and the biosphere and geosphere, the water sources used for drinking purposes generally contain natural organic matter (NOM) but during rainy season and floods its amount increases much more in surface and ground water inhibiting the oxidation of iron by reducing it from $\mathrm{Fe}^{+3}$ to $\mathrm{Fe}^{+2}$, and as a result concentration of iron in water is increased. Intake of high contents of iron via food or drink may result toxic effects in human body. The formation of hydroxyl radicals and deposition of iron (due to these $\mathrm{Fe}^{+2}$ ions) in a typical kidney cell may harm kidney cells. The excess amount of iron may accelerate the formation of free radicals resulting in instigation of mutagenicity, nephrotoxicity and renal carcinoma [29].

\section{Health risk assessment}

In present study, health risk assessment due to elevated concentration of $\mathrm{As}, \mathrm{Fe}, \mathrm{Mn}$ and $\mathrm{Zn}$ in groundwater was carried out by measuring chronic daily intake (CDI) and health risk index (HRI) values for both children and adults as shown in Table 1. Calculated CDI values for children ranged from 0.003-0.092, 0.000-0.917, 0.000-0.807 and $0.015-0.138 \mu \mathrm{g} \cdot \mathrm{kg}^{-1} \cdot \mathrm{day}^{-1}$ and in the case of adults CDI varied from $0.003-0.083,0.000-0.833,0.000-0.733$ and $0.014-0.125 \mu \mathrm{g} \cdot \mathrm{kg}^{-1} \cdot \mathrm{day}^{-1}$ for $\mathrm{Fe}, \mathrm{Mn}, \mathrm{As}$ and $\mathrm{Zn}$ respectively. Calculated CDIs were found in the order of $\mathrm{Mn}>\mathrm{As}>\mathrm{Zn}>\mathrm{Fe}$.

HRI values were high for As, ranging from 0.000-2.691 (mean=1.001) for children and from 0.000-2.444 (mean=0.909) for adults and overall 46 and $37 \%$ water samples have HRI $>1$ in children and adults respectively. HRI for Fe ranged from 4.37E-06 to $1.31 \mathrm{E}-04$ and 3.97E-06 to 1.19E-04, Mn from 0.000-0.038 and 0.000-0.035 and $\mathrm{Zn}$ HRI varied from $5.10 \mathrm{E}-05$ to $4.59 \mathrm{E}-04$ and $4.63 \mathrm{E}-05$ to $4.17 \mathrm{E}-04$ for both children and adults respectively which indicate that $\mathrm{HRI}<1$ for $\mathrm{Fe}, \mathrm{Mn}$ and $\mathrm{Zn}$. Comparison of mean HRI values for 08 union councils revealed that ground water of Kot Mithan, Noorpur and Sabzani union councils is more prone to health hazards as is evident from high mean HRI, which is greater than 1 for both children and adults as compared to other union councils as shown in Table 2 whereas mean HRI of As and other heavy metals is less than 1 in all other union councils. HRI calculations showed that heavy metals in ground water of district Rajanpur were found in order of $\mathrm{As}>\mathrm{Mn}>\mathrm{Zn}>\mathrm{Fe}$.

Groundwater samples having HRI $>1$ highlight future consumer's health risk associated with intake of this water for drinking purpose. Literature shows high to very high carcinogenic and non-carcinogenic health risk for adults and children associated with elevated As concentration in drinking water and its correlation with $\mathrm{Fe}$ and other heavy metals [30].

\section{Microbiological monitoring}

Pathogens associated with contamination of water sources pose an adverse health risks to men, women and children of all ages because nearly $80 \%$ of total diseases including diarrhoea, hepatitis, dental caries, oral hygiene and anaemia in children are associated with drinking contaminated water [31]. Study presented here showed that $75 \%$ water samples were found contaminated with total coliform whereas $57 \%$ were having faecal coliform organism as shown in Figure 4. Contamination of groundwater sources was evident from high level of open air defecation and practice of tethering animals close to human dwellings. Rain and flood water carry these human and animal's faecal wastes, which may carry pathogens and contaminates the water sources in the region and direct consumption from these sources may cause infectious diseases [32].

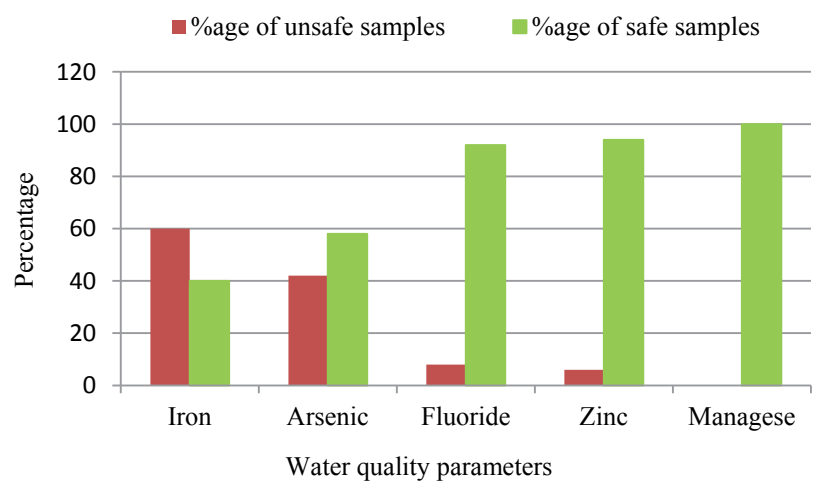

Figure 3: Samples (\%age) safe and unsafe as compared to GVs.

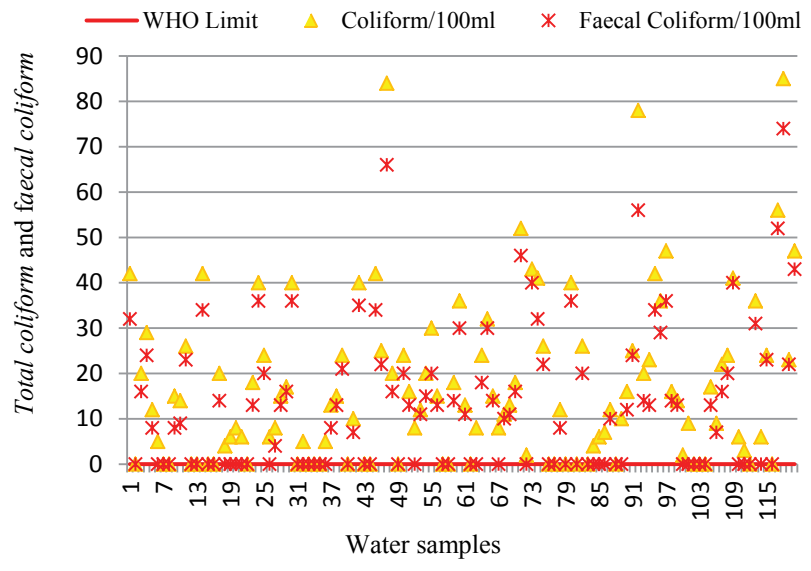

Figure 4: Comparison of total coliform and faecal coliform with WHO GVs. 
Citation: Sarfraz MD, Sultana N, Jamil MD, Ashraf R (2016) Investigation of Portable Groundwater Quality and Health Risk Assessment of Selected Trace Metals in Flood Affected Areas of District Rajanpur, Pakistan. J Environ Anal Chem 3: 183. doi:10.41722380-2391.1000183

Page 4 of 5

\begin{tabular}{|c|c|c|c|c|c|}
\hline \multirow{2}{*}{ Metals } & & \multicolumn{2}{|c|}{ CDI } & \multicolumn{2}{c|}{ HRI } \\
\cline { 2 - 6 } & & Children & Adults & Children & $3.97 \mathrm{E}-06$ to $1.19 \mathrm{E}-04$ \\
\hline \multirow{2}{*}{ Fe } & Range & $0.003-0.092$ & $0.003-0.083$ & $4.37 \mathrm{E}-06$ to $1.31 \mathrm{E}-04$ & $2.24 \mathrm{E}-05$ \\
\cline { 2 - 6 } & Mean & 0.017 & 0.016 & $2.47 \mathrm{E}-05$ & $0.000-0.035$ \\
\hline \multirow{2}{*}{ Mn } & Range & $0.000-0.917$ & $0.000-0.833$ & $0.000-0.038$ & 0.024 \\
\cline { 2 - 6 } & Mean & 0.621 & 0.564 & 0.026 & $0.000-2.444$ \\
\hline \multirow{2}{*}{ As } & Range & $0.000-0.807$ & $0.000-0.733$ & $0.000-2.691$ & 0.909 \\
\cline { 2 - 6 } & Mean & 0.3 & 0.273 & 1.001 & $4.63 \mathrm{E}-05$ to $4.17 \mathrm{E}-04$ \\
\hline \multirow{2}{*}{$Z \mathbf{Z n}$} & Range & $0.015-0.138$ & $0.014-0.125$ & $5.10 \mathrm{E}-05$ to $4.59 \mathrm{E}-04$ & $1.02 \mathrm{E}-04$ \\
\cline { 2 - 6 } & Mean & 0.034 & 0.031 & $1.13 \mathrm{E}-04$ & \\
\hline
\end{tabular}

Table 1: Calculated range and mean values of CDI and HRI of trace metals.

\begin{tabular}{|c|c|c|c|c|c|c|c|c|}
\hline \multirow{2}{*}{ Union Councils } & \multicolumn{2}{|c|}{ Fe HRI } & \multicolumn{2}{|c|}{ Mn HRI } & \multicolumn{2}{|c|}{ As HRI } & \multicolumn{2}{|c|}{ Zn HRI } \\
\hline & Children & Adults & Children & Adults & Children & Adults & Children & Adults \\
\hline Jahanpur & 2.77E-05 & $2.51 \mathrm{E}-05$ & 0.025 & 0.023 & 1.009 & 0.917 & 1.26E-04 & 1.14E-04 \\
\hline Kot Mithan & 2.21E-05 & 2.01E-05 & 0.028 & 0.025 & 1.145 & 1.040 & $9.24 \mathrm{E}-05$ & 8.40E-05 \\
\hline Miranpur & 4.69E-05 & 4.26E-05 & 0.027 & 0.025 & 0.867 & 0.787 & $9.51 \mathrm{E}-05$ & 8.64E-05 \\
\hline Murgai & $1.51 \mathrm{E}-05$ & 1.38E-05 & 0.021 & 0.019 & 0.802 & 0.728 & 9.65E-05 & 8.77E-05 \\
\hline Norpur & 1.67E-05 & $1.52 \mathrm{E}-05$ & 0.027 & 0.024 & 1.333 & 1.211 & $6.80 \mathrm{E}-05$ & $6.17 \mathrm{E}-05$ \\
\hline Sabzani & $3.51 \mathrm{E}-05$ & 3.19E-05 & 0.026 & 0.023 & 1.566 & 1.422 & 9.85E-05 & 8.95E-05 \\
\hline Shakarpur & $1.28 \mathrm{E}-05$ & 1.16E-05 & 0.026 & 0.024 & 0.565 & 0.514 & 2.07E-04 & $1.88 \mathrm{E}-04$ \\
\hline Wang & $2.10 \mathrm{E}-05$ & 1.90E-05 & 0.027 & 0.025 & 0.719 & 0.653 & 1.19E-04 & $1.08 \mathrm{E}-04$ \\
\hline
\end{tabular}

Table 2: Comparison of calculated HRI due to trace metals at union council level.

\section{Conclusion}

Physicochemical and microbiological assessment of groundwater being used for drinking purpose by residents of district Rajanpur revealed that there was high level of microbial contamination as $75 \%$ sites were found contaminated with total coliforms and 57\% were overloaded with faecal coliform bacteria. The study also highlighted that a large number of sites were polluted with other chemicals, minerals and trace metals like $\mathrm{Ca}, \mathrm{SO}_{4}, \mathrm{Na}, \mathrm{K}, \mathrm{Fe}$, As and TDS. Health risk assessment showed that HRI $>1$ for As in 46 and 37\% water samples for children and adults respectively. Net result of present study is that most of the waterborne diseases prevailing in the region are due to consumption of substandard water after flood. A concrete policy should be devised to treat the ground water and address post-flood environmental effects on life and human health so that safety from hazardous effects associated with bacterial contamination and elevated concentration of toxic components may be ensured.

\section{Conflict of Interest}

The authors declare no conflict of interest for compiling and submission of this article.

\section{References}

1. Malik MA, Azam EM, Saboor A (2010) Water Quality Status of Upper KPK and Northern Areas of Pakistan, Water Resources Research Center, Peshawar, Ministry of Science and Technology, Peshawar Publications, Report No: 142.

2. Phiri O, Mumba P, Moyo B, Kadewa W (2005) Assessment of the impact of industrial effluents on water quality of receiving rivers in urban areas of Malawi. International Journal of Environmental Science \& Technology 2: 237-244.

3. WHO (1996) Trace elements in human nutrition and health.

4. Memon M, Soomro MS, Akhtar MS, Memon KS (2011) Drinking water quality assessment in Southern Sindh (Pakistan). Environmental monitoring and assessment 177: 39-50.

5. Asia DS (2000) Water vision 2025. Country Report, Pakistan, Maharashtra, India, Global Water Partnership, South Asia Technical Advisory Committee Regional Office.

6. Khan S, Shahnaz M, Jehan N, Rehman S, Shah MT, et al. (2013) Drinking water quality and human health risk in Charsadda district, Pakistan. Journal of cleaner production 60: 93-101.
7. Gripenberg-Lerche C, Zhang L, Ahtonen P, Toivanen P, Skurnik M (2000) Construction of urease-negative mutants of Yersinia enterocolitica serotypes O: 3 and O: 8: role of urease in virulence and arthritogenicity. Infection and immunity 68: 942-947.

8. Baig SA, Xu X, Navedullah MN, Khan ZU (2012) Pakistan's drinking water and environmental sanitation status in post 2010 flood scenario: humanitarian response and community needs. Journal of Applied Sciences in Environmental Sanitation 7: 49-54.

9. Rasool A, Farooqi A, Masood S, Hussain K (2016) Arsenic in groundwater and its health risk assessment in drinking water of Mailsi, Punjab, Pakistan. Human and Ecological Risk Assessment: An International Journal 22: 187-202.

10. Perveen F, Asghar U, Usmani TH (2007) Evaluation of Water Quality of Different Colleges of Karachi City. Journal of the Chemical Society of Pakistan 29: 458-462.

11. Spalding RF, Exner ME (1993) Occurrence of nitrate in groundwater-a review. Journal of environmental quality 22: 392-402.

12. Laluraj C, Gopinath $G$ (2006) Assessment on seasonal variation of groundwater quality of phreatic aquifers-a river basin system. Environmental monitoring and assessment 117: 45-57.

13. Wakida FT, Lerner DN (2005) Non-agricultural sources of groundwater nitrate: a review and case study. Water research 39: 3-16.

14. WHO (2010) World health statistics 2010. World Health Organization.

15. Apha A (2005) WEF, 2005. Standard methods for the examination of water and wastewater 21: 258-259.

16. dll Version P (2003) Method 1603: Escherichia coli (E. coli) in Water by Membrane Filtration Using Modified membrane-Thermotolerant Escherichia coli Agar (Modified mTEC).

17. Shah M, Ara J, Muhammad S, Khan S, Tariq S (2012) Health risk assessment via surface water and sub-surface water consumption in the mafic and ultramafic terrain, Mohmand agency, northern Pakistan. Journal of Geochemical Exploration 118: 60-67.

18. Khan S, Rehman S, Khan AZ, Khan MA, Shah MT (2010) Soil and vegetables enrichment with heavy metals from geological sources in Gilgit, northern Pakistan. Ecotoxicology and Environmental Safety 73: 1820-1827.

19. Muhammad S, Shah MT, Khan S (2010) Arsenic health risk assessment in drinking water and source apportionment using multivariate statistical techniques in Kohistan region, northern Pakistan. Food and Chemical Toxicology 48: 2855-2864. 
Citation: Sarfraz MD, Sultana N, Jamil MD, Ashraf R (2016) Investigation of Portable Groundwater Quality and Health Risk Assessment of Selected Trace Metals in Flood Affected Areas of District Rajanpur, Pakistan. J Environ Anal Chem 3: 183. doi:10.41722380-2391.1000183

Page 5 of 5

20. Idoko OM (2010) Seasonal Variation in Iron in Rural Groundwater of Benue State, Middle Belt, Nigeria. Pakistan Journal of Nutrition 9: 892-895

21. Azizullah A, Khattak MNK, Richter P, Häder D-P (2011) Water pollution in Pakistan and its impact on public health- a review. Environment International 37: 479-497.

22. DeSimone R, Currie K, Mitchell S, Darrow J, Pippin D (2004) Privileged structures: applications in drug discovery. Combinatorial chemistry \& high throughput screening 7: 473-493.

23. Hakim ST, Afaque F, Javed S, Kazmi SU, Nadeem SG (2014) Microbial agents responsible for diarrheal infections in flood victims: a study from Karachi, Pakistan. Open Journal of Medical Microbiology p: 9.

24. Plé PA, Green TP, Hennequin LF, Curwen J, Fennell M, et al. (2004) Discovery of a new class of anilinoquinazoline inhibitors with high affinity and specificity for the tyrosine kinase domain of c-Src. Journal of medicinal chemistry 47: 871-887.

25. Mobley H, Island MD, Hausinger RP (1995) Molecular biology of microbial ureases. Microbiological reviews 59: 451-480.
26. Ashbolt NJ (2004) Microbial contamination of drinking water and disease outcomes in developing regions. Toxicology 198: 229-238.

27. Adepoju-Bello A, Alabi O (2005) Heavy metals: A review. The Nig J Pharm 37: $41-45$

28. Witt A, Bergman J (2003) Recent developments in the field of quinazoline chemistry. Current Organic Chemistry 7: 659-677.

29. Mhaske SB, Argade NP (2006) The chemistry of recently isolated naturally occurring quinazolinone alkaloids. Tetrahedron 62: 9787-9826.

30. Van Halem D, Olivero S, de Vet W, Verberk J, Amy G, et al. (2010) Subsurface iron and arsenic removal for shallow tube well drinking water supply in rura Bangladesh. Water research 44: 5761-5769.

31. Brume-Jensen P, Hunter T (2001) Oncogenic kinase signaling. Nature 411 355-365.

32. Bablani SA, Soomro SA (2006) Evaluation of seawater intrusions in left bank sediments of coastal district Thatta, Sindh, Pakistan. 1st SWIM-SWICA Joint Saltwater Intrusion Conference. 